\title{
COLLABORATIVE INITIATIVES: MOTIVATORS, BARRIERS AND BENEFITS
}

\author{
DENISE C. DE FREITAS ${ }^{1}$ \\ (iD) https://orcid.org/0000-0003-3425-3551 \\ LEANDRO G. DE OLIVEIRA ${ }^{2}$ \\ (iD https://orcid.org/0000-0003-0231-679X \\ ROSANE L. C. ALCANTARA ${ }^{2}$ \\ (iD) https:/orcid.org/0000-0002-7018-5456
}

To cite this paper: Freitas, D. C., Oliveira, L. G., \& Alcantara, R. L. C. (2018). Collaborative initiatives: Motivators, barriers and benefits. Revista de Administração Mackenzie, 19(3). doi:10.1590/ 1678-6971/eRAMR170126

Submission: Dec. 08, 2017. Acceptance: Fev. 07, 2018.

1 Instituto Federal de São Paulo (Ifsp), São Paulo, SP, Brazil.

2 Universidade Federal de São Carlos (Ufscar), São Carlos, SP, Brazil.

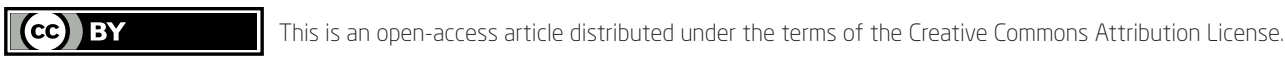

\footnotetext{
This paper may be copied, distributed, displayed, transmitted or adapted if provided, in a clear and explicit way, the name of the journal, the edition, the year and the pages on which the paper was originally published, but not suggesting that RAM endorses paper reuse. This licensing term should be made explicit in cases of reuse or distribution to third parties. It is not allowed the use for commercial purposes.

Este artigo pode ser copiado, distribuído, exibido, transmitido ou adaptado desde que citados, de forma clara e explícita, o nome da revista, a edição, o ano e as páginas nas quais o artigo foi publicado originalmente, mas sem sugerir que a RAM endosse a reutilização do artigo. Esse termo de licenciamento deve ser explicitado para os casos de reutilização ou distribuição para terceiros. Não é permitido o uso para fins comerciais.
} 


\section{ABSTRACT}

Purpose: To propose a classification of the different types of motivators, barriers and benefits existing in the processes of adoption of collaborative initiatives between companies within the supply chain.

Originality/value: The results achieved assist managers to know the different types of motivators that drive the adoption of these initiatives, the benefits that can be achieved and the barriers that can be encountered, hence avoiding unsuccessful implementations. Researchers provide a better theoretical understanding of the different types of components present in these initiatives, paving the way for the search for empirical evidence.

Design/methodology/approach: A systematic review of the literature, focusing on five initiatives: Quick Response (QR), Efficient Consumer Response (ECR), Continuous Replenishment Program (CRP), Vendor Managed Inventory (VMI), and Collaborative Planning, Forecasting and Replenishment (CPFR).

Findings: The motivators for adopting these initiatives are related to the economic or market changes and/or the organization of these companies. The barriers are classified as cultural, behavioral and physical and the benefits are classified as primary and secondary; showing that the primary benefits must be achieved in order for the secondary benefits to appear. The work shows that despite the use of similar nomenclatures, the concepts used may be different for various contexts. In addition, the work shows that information and communication technologies cease to be a barrier and become a facilitator for companies interested in collaborating in their supply chain. The importance of human resources is also highlighted.

\section{KEYWORD}

Motivators. Barriers. Benefits. Collaboration. Supply chain. 


\section{INTRODUCTION}

Reducing the lifecycle and increasing demand for customized products makes the demand forecasting process highly complex. In this sense, Tyan and Wee (2003) comment on the need to share information among partners in the supply chain. For Marqués, Lamothe, Thierry, and Gourc (2012), the collaborative initiatives make this process possible, moreover, helping to control the production and inventory.

Collaborative initiatives emerged in the 1980s as a way to increase levels of cooperation between organizations, providing improvements in the performance of the supply chain. The management of these initiatives coordinates supply, production and delivery by balancing production with demand (Vigtil \& Dreyer, 2008), which can result in waste reduction, improvement in customer satisfaction and greater responsiveness (Gao, Liu, \& Liu, 2005).

The collaborative initiatives analyzed in this article are: Quick Response (QR), Efficient Consumer Response (ECR), Continuous Replenishment Program (CRP), Vendor Managed Inventory (VMI), and Collaborative Planning, Forecasting and Replenishment (CPFR). According to Gomes and Kliemann Neto (2015), these are the most popular initiatives in the academic field.

QR is a strategy that improves the efficiency and the level of customer service without compromising the variety of products (Forza \& Vinelli, 1997). ECR encourages information sharing, trust and supply chain efficiency (Whipple \& Russel, 2007). CRP is a collaborative trade in which retailers outsource purchasing decisions and inbound logistics to manufacturers (Lee, Pak, \& Lee, 2003). VMI is a strategy in which the vendor is given responsibility for managing the customer's inventory (Blackhurst, Craighead, \& Handfield, 2006). Finally, the CPFR attempts to eliminate planning problems through real-time point-of-sale information sharing (Barratt \& Oliveira, 2001).

Despite the large number of studies in the literature, the vast majority addresses a particular initiative and focuses on existing barriers, expected or motivating benefits to its adoption. Others consider more than an initiative but do not focus on these three aspects together, (e.g., Birtwistle, Fiorito, \& Moore, 2006; Mangiaracina, Melacini, \& Perego, 2012). Other works only analyze the benefits achieved (e.g., Savaşaneril \& Erkip, 2010), but few studies comment on these initiatives jointly (e.g., Derrouiche, Neubert, \& Bouras, 2008). 
The present article advances in existing knowledge by proposing a theoretical classification of the different types of motivators, barriers and benefits that exist in the adoption of collaborative initiatives. It is believed that the presented results can help this process between companies in the supply chain; in addition, to increase the knowledge about these initiatives, contributing to the consolidation of their theoretical development.

In addition to this introductory section, the study is organized into four sections. The second section addresses the method used in the study, specifically the systematic review of the literature. The third one highlights the collaborative initiatives, their motivators, their barriers and their benefits, and also presents a conceptual model of implementation of the initiatives. In the fourth section, the final considerations of the study are presented.

\section{METHOD}

The systematic review of the literature seeks to guarantee the depth and rigor, which is usually lacking in narrative reviews, based on a specific methodology of data analysis and synthesis, with a careful selection and evaluation of existing studies (Denyer \& Tranfield, 2009). Colicchia and Strozzi (2012, pp. 404-405) argue that the systematic review of the literature "... offers a solid and reliable technique that can be easily applied to large fields of research to select the most relevant contributions". The systematic review of the literature of this article was based on the five steps proposed by Denyer and Tranfield (2009) (Figure 2.1).

The first step corresponds to the review question, which according to the research objective was: "What are the motivators, barriers and benefits of the collaborative initiatives in the supply chains QR, ECR, CRP, VMI and CPFR?" Factors external to the company that contribute to its adoption are understood as motivators. Barriers are all elements that hinder the process of implementing an initiative. Finally, the benefits are the results obtained with the adoption of the initiative.

The second stage is related to the location of studies, identification of keywords and choice of databases (Colicchia \& Strozzi, 2012). The searches were conducted between January and July 2014 and updated in December 2015 and involved the name or acronym of the initiative in the title, abstract or keywords, with the terms "supply chain" and "collabo" anywhere in the article in the databases: Scopus, Web of Science, EBSCOhost, Emerald and SciELO. In all databases the same criteria were used, respecting their particularities. 


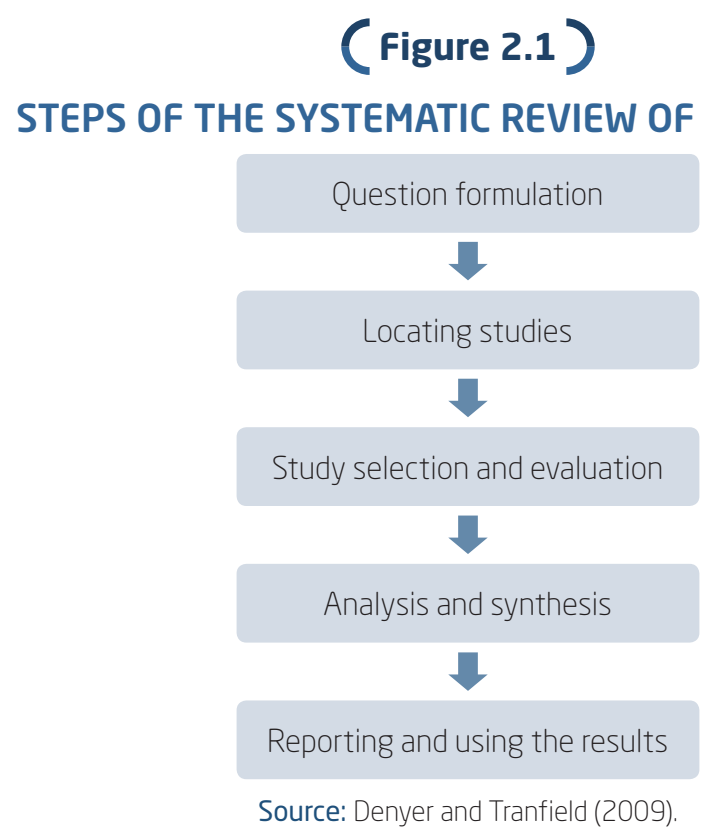

The choice of the Scopus and Web of Science databases was based on the work of Buchinger, Cavalcanti, and Hounsell (2014), who list them as important search engines because they have many resources. The EBSCO host database was selected for having the largest coverage in the supply chain area (Wong, Skipworth, Godsell, \& Achimugu, 2012). The Emerald database was used for presenting very important works, which were not selected in the searches of the other databases. Finally, with the database SciELO, we attempted to capture the works of Brazilian authors.

Since the focus of this review of the literature is rather broad, no time limit has been imposed on research. Despite this, no articles were found prior to 1997. Both qualitative and quantitative articles were used and the methodology used (survey, case study, simulation, etc.) was not considered a criterion for exclusion.

The next step is the selection and evaluation of the studies. In this step, the definition of the inclusion and exclusion criteria is important to select the documents relevant to the research (Denyer \& Tranfield, 2009) (Table 2.1). Documents that were not articles or reviews were deleted to increase the quality of the search. Only articles in Portuguese or English were selected, which guarantees a good representation on the subject. Duplicate works have been removed and only those available for download have been retained. Finally, the texts were read in full and those that did not present contributions 
on characteristics, motivators, barriers, and benefits were excluded, a total of 124 documents.

\section{(Table 2.1)}

CRITERIA FOR INCLUSION AND EXCLUSION OF RSL

\begin{tabular}{ll}
\multicolumn{2}{c}{ Criteria for inclusion and exclusion from the systematic literature review } \\
\hline Articles and reviews & Inclusion \\
\hline Articles in English and Portuguese & Inclusion \\
\hline Congress products & Exclusion \\
\hline Duplicate articles & Exclusion \\
\hline Available for download & Inclusion \\
\hline Mention features, benefits, barriers and motivators & Inclusion \\
\hline
\end{tabular}

Source: Elaborated by the authors.

The fourth step refers to the analysis and synthesis of the documents; extracting the relevant data from the literature. For each initiative, the three categories (motivators, barriers and benefits) were extracted. They were later grouped by means of an iterative (deductive-iterative) process, so that the constructs created (categories) were representative, containing elements with similar meanings according to the work of Marqui, Moura, and Alcântara (2013).

The fifth step is the development of the report with the adopted procedures, results and conclusions found, enabling the replicability of the study (Okoli \& Schabram, 2010). Finally, the description and classification of the motivators, barriers and benefits of the collaborative initiatives studied are presented in section 3 .

\section{DESCRIPTION, MOTIVATORS, BARRIERS AND BENEFITS OF COLLABORATIVE INITIATIVES}

This section will present the motivators, barriers and benefits of the five collaborative initiatives. Firstly, a description of each of the initiatives is made, emphasizing the year of development, the sector in which they were implemented and their evolution over the years. Following that, the 
motivators, barriers and benefits of collaborative initiatives will be addressed. Finally, a conceptual model of implementation is presented.

\subsection{Brief description of the QR, ECR, CRP, VMI, and CPFR initiatives}

For Birtwistle, Siddiqui, and Fiorito (2003), the QR was developed in the USA in the 1980s between suppliers and retailers of fashion articles. It is a just-in-time (JIT) strategy, in which the concept involves delivering raw materials to production in the exact quantity and timeframe, in order to reduce the inventory of the entire supply chain (Harris, Swatman, \& Kurnia, 1999).

ECR emerged in the early 1990s, in the grocery industry, encouraging information sharing and developing trust and efficiency (Whipple \& Russel, 2007). The ECR consists of an extension of the QR (Derrouiche et al., 2008; Hoffman \& Mehra, 2000; Soret, Pablos, \& Montes, 2008), transforming the supply chain from a push to a pull system, in which trading partners relate through strategic alliances and replenishment begins from point-of-sale data (Harris, Swatman, \& Kurnia, 1999).

Tyan and Wee (2003) believe that the concept of CRP has been developed from the ECR, in which products are no longer pushed from inventories and are pulled from consumer demand. The CRP deals with demand uncertainty (Lee et al., 2003) by coordinating supply chain members to work with common forecasts. It introduces two innovations: the retailer must share its inventory levels, which were traditionally viewed as sensitive and secret information; and the inventory management of the retailer is made by the manufacturers (Raghunathan \& Yeh, 2001).

$\mathrm{VMI}$ is a business practice in which the vendor is responsible for managing customer inventory, determining replenishment policies (Birtwistle et al., 2006; Blackhurst et al., 2006; Disney \& Towill, 2003, Freitas, Tomas, \& Alcântara, 2014). Specifically, Kauremaa, Småros, and Holmström (2009) define the VMI in terms of two basic conditions: 1. transfer of decisions and responsibilities related to replenishment of the buyer to the supplier; 2. increased visibility promoted by the buyer, so that the supplier fulfills its additional responsibility.

The concept of CPFR was introduced with a pilot project. In 1995, Caridi, Cigolini, and Marco (2006) affirmed that in it, the seller and buyer collaborate by adjusting and proposing prices and quantities to generate a single forecast. For Chang, Fu, Lee, Lin, and Hsueh (2007), CPFR integrates 
the supply and demand sides, allowing the collective creation of an effective environment to meet consumer demands. CPFR improves retailers' predictions and ability to respond quickly to market changes.

Figure 3.1.1 presents a summary of the main characteristics of each initiative and a chronological scale of development, aiming to situate the period of diffusion in the academic and business environment. The arrow at the bottom of the figure shows that information and communication technologies have been improving and evolving over time, increasing the exchange of information among supply chain partners and, consequently, increasing the visibility of demand, which also allowed for the development of new strategies and initiatives.

The division of Figure 3.1.1 between specific and evolutionary characteristics of the collaborative initiatives differentiate those that have been improved from those that are specific to each one and are not addressed by the others. In this way, the focus of all initiatives on improving the replenishment process is highlighted, from the $\mathrm{QR}$ that aimed at reducing delivery cycles, through the ECR, CRP and VMI that attempt to achieve efficient replenishment through continuous replenishment (CRP) and supplier replenishment (VMI), to the CPFR, which seeks collaborative replenishment. In the CRP, the supplier already takes responsibility for inbound purchasing and logistics decisions, a concept that is improved in VMI by transferring responsibility for refueling to the supplier. VMI evolves further by attempting to synchronize internal productive operations with chain demand; and the CPFR, in addition to performing collaborative replenishment, still performs the forecasting and planning processes in a collaborative way, which in a way, also promotes the synchronization between productive operations and demand. 


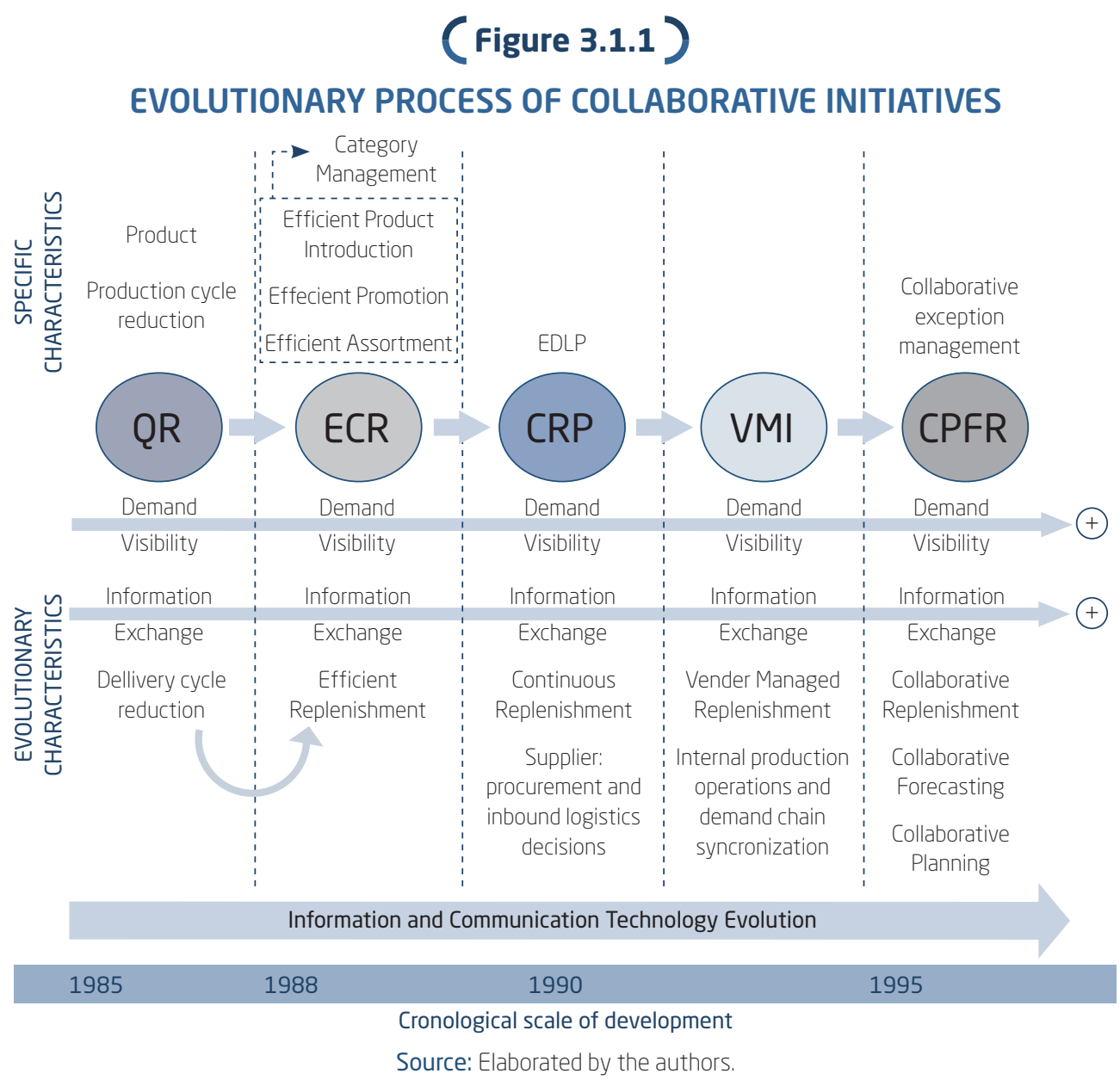

\subsection{Motivators, barriers and benefits of collaborative initiatives}

In order to characterize the different types of motivators, barriers and benefits found in the adoption of the collaborative initiatives studied, it was proposed to classify their different elements into groups with homogeneous characteristics, which will be discussed below.

\subsubsection{Motivators}

The analysis of the motivators to the adoption of the collaborative initiatives studied led to their division into two groups: economic and organizational motivators. Economic motivators are external factors to the 
supply chain, arising from an economic factor or by a market event that encourages companies to adopt collaborative initiatives reactively. Organizational motivators are internal factors to the supply chain, related to the form of organization of the companies that lead to the adoption of the collaborative initiative.

\section{Economic motivators}

- Among the economic motivators are: more intense competition; demand, product and market characteristics; globalization; and reaction to the market.

- More intense competition: the strong competition between companies and the arrival of foreign companies require companies to adopt new practices to become more efficient, guaranteeing their competitiveness in the market.

- Demand, product and market characteristics: a common point between $\mathrm{QR}, \mathrm{VMI}$ and CPFR initiatives is the challenge for companies to address the reduction of the product life cycle. In $\mathrm{QR}$, the trend of textile products stimulated the adoption of this initiative, in search of the reduction of the time to better satisfy the needs of the market. In ECR, the complexity of dealing with information from various points of sale, changes in consumer needs and the market's difficulty in accepting price increases were the factors that encouraged the adoption of this tool. VMI was adopted to reduce product lifecycle and complexities involved in production and distribution. CPFR also begins to be adopted to reduce the product lifecycle and its innovative nature and the duration of retail trends.

- Globalization: it is an important factor that determines the adoption of the initiatives of collaboration, being mentioned in the initiatives of $\mathrm{QR}$, VMI and CPFR.

- Market reaction: once companies introduce collaborative initiatives in their markets, they can increase their competitive advantage and other companies realize the need to follow them.

\section{Organizational motivators}

- Among the organizational motivators for implementation are: supply chain problems, previous experiences and pressure from trading partner.

- Supply chain problems: the common case of QR adoption was the need to restructure the textile industry, which had high response times with inaccurate forecasts and inventory failures. The ECR was adopted when 
inefficiencies along the chain became evident. The difficulty in forecasting and the level of uncertainty in the operations of buyers and suppliers were cited as motivators for the adoption of VMI. CPFR was adopted to reduce the cost structure of the supply chain, in addition to the need for better information on demand.

- Previous experiences: in QR, previous experiences were not cited as a motivator for adoption, while for CPFR practice, there were references to VMI and ECR as facilitators of adopting the former. This result suggests the existence of an evolutionary process between these initiatives, starting with QR and CPFR as the most advanced initiative. In addition, a motivator for the adoption of the ECR cited was the EDI already implemented among the companies and in the VMI, multifunctional relationships already existing between the partners.

- Pressure from trading partner: in ECR and VMI, there is a transfer of responsibility for category management and the process of replenishing from a partner with greater power to the lesser one, which allows the first to receive bonuses for improvement and to transfer costs. In the CPFR, it is assumed that the processes are carried out collaboratively, which makes the transfer of responsibilities unfeasible, since both parties must be determined to review their processes.

\subsubsection{Barriers}

The analysis of the barriers showed to be pertinent grouping them in cultural, physical and behavioral, according to the work of Freitas et al. (2014). According to these authors, cultural barriers are related to the organization and influence the implementation and maintenance of the initiatives; the behavioral ones are related to the willingness of the companies to collaborate in the supply chain; and finally, physical barriers relate to the technology and resources needed to implement the initiatives.

\section{Cultural barriers}

- Among the cultural barriers, those evidenced in the literature were: lack of training for new mindsets and skills; different goals and objectives; lack of relationship orientation; lack of capacity to share risks and rewards, difficulties in integrating key processes; inflexible organizational systems and processes; inadequate performance measures, lack of top management support; lack of cross-functional coordination; incompatible organizational culture; lack of formalization of processes and documents; 
lack of joint planning; lack of customer service focus and goals; problem solving and making decisions on an individual basis.

- Lack of training for new mindsets and skills: these elements hamper the process of implementing collaborative initiatives since employees do not understand their concepts and how they change their activities and functions in the organization.

- Different goals and objectives: the lack of establishment of objectives and goals shared between the partners and aligned with the corporate strategies of the companies generate conflicts of interests that limit the potential of success of the initiatives.

- Lack of relationship orientation: it is important for companies to understand the partner's business and desire to collaborate to satisfy mutual interests. In addition, to enable the implementation process, top management support is essential.

- Lack of capacity to share risks and rewards: the actors' perception that risks, costs and benefits are not being distributed in a balanced way hinders the collaborative relationship.

- Difficulties in integrating key processes: the lack of a clear explanation of which processes should be integrated into each initiative makes analysis difficult, since each author presents a specific difficulty in a relationship or in relation to only one process. An interesting point to note, however, is that in the $\mathrm{QR}$ there is the mention of processes that are unsuitable for the initiative and others that are difficult to integrate, while for other initiatives (ECR, VMI and CPFR) there is already a concern about the difficulty in modifying processes to achieve integration.

- Inflexible organizational systems and processes: the authors comment that several processes must be changed and new ones must be introduced for the success of the initiatives.

- Inadequate performance measures: performance measures should be designed to monitor the outcome of initiatives and should be aligned with company strategies. In addition, it is important to take customer needs into account in setting the objectives, goals and performance measures of the initiative.

- Lack of top management support: the lack of management support makes it difficult for other members of the organization to support the implementation of initiatives, making it difficult for multifunctional teams to compromise.

- Lack of cross-functional coordination: the adoption of ECR, VMI and $\mathrm{CPFR}$ requires multifunctional and interorganizational teams but in 
$\mathrm{QR}$ it was not reported as a barrier. This result may show that QR emphasizes aspects of external integration before even focusing on internal integration.

- Incompatible organizational culture: organizational cultures should support collaborative relationships and be compatible with business partners.

- Lack of formalization of processes and documents: presented aspects such as definition of roles and responsibilities within the initiative is a difficulty faced by companies. Despite this, few authors perceive this need, since with the increase of trust and training of the human resources, the need to formalize processes and documents is no longer relevant.

- Lack of joint planning: in the CPFR, it relates to the lack of discipline of the companies to carry out the initial phases of the process. In the ECR, it is related to the lack of development of a joint plan, with prioritization of ECR and category management.

- Lack of customer service focus and goals: in the ECR, the focus on cost efficiency without proper concern for consumer needs results in unsuccessful implementations. Contrary to expectations, however, only one author who talks about CPFR cited the lack of emphasis on the final consumer as a barrier. In the $\mathrm{QR}$, there was only one mention in this regard, commenting that each company in the chain has a relationship and therefore, a different understanding of the final consumer.

- Problem solving and decision making on an individual basis: since CPFR assumes that planning, forecasting and replenishment processes are done collaboratively, this element may be a prerequisite to adopting CPFR.

\section{Behavioral barriers}

- Behavioral barriers are: a lack of trust; inability or unwillingness to share information; problems in information and communication flow; resistance to change; and lack of commitment.

- Lack of trust: cooperation, collaboration and respect between partners are the fruit of developing trust between them. It is interesting to note that lack of trust prevents the development of collaborative relationships but over time and maturity of the relationship, trust becomes an important success factor of the relationship.

- Inability or unwillingness to share information: companies' fear of sharing information impedes the implementation of initiatives, since the basis for any of them is the exchange of information. 
- Problems in information and communication flow: resulting in data and information inaccuracies that detract from the performance of the entire chain.

- Resistance to change: it can be mitigated by employee training.

- Lack of commitment: it hinders the development of trust and undermines the performance of collaborative initiatives.

\section{Physical barriers}

- The physical barriers, as discussed below, are: insufficient investments in IT/IS and telecommunications; insufficient financial resources; other investments insufficient.

- Insufficient IT/IS and telecommunication investments: it is interesting to note that while in $\mathrm{QR}$ the concerns regarding information and communication technologies were centered on the high cost of implementation and lack of knowledge about the available technologies, in VMI it is seen almost as a prerequisite for the adoption and reduction of technology related costs. In the ECR, technology has an intermediate role in relation to $\mathrm{QR}$ and VMI. While the lack of technological capacity is seen as a barrier, the lack of system integration and flexibility are already beginning to be perceived as barriers, besides the high cost of implementation. In CPFR, it is also treated as a facilitator, with the main barriers related to systems that aid decision making, as well as the costs and incompatibility of information systems.

- Insufficient financial investments: the high investment required for the implementation of these initiatives can be an obstacle, specifically for smaller companies.

- Other insufficient investments: time required for implementation of initiatives, human resources and facilities.

\subsubsection{Benefits}

The benefits of the collaborative initiatives studied were divided into two groups: primary and secondary.

\section{Primary benefits}

- Among the primary benefits are: better inventory management; better demand predictability; better planning; replenishment process improvement; improvement of the productive cycle; relationship 
improvement; improved supply chain management; improvement of product assortment; improvement of promotional activities; reduced cycle time; higher efficiency in product launching.

- Better inventory management: collaborative initiatives can reduce the inventory level in the supply chain as a whole, while reducing stockouts and increasing inventory turnover. One of the consequences of better inventory management is the availability of fresher and better quality products in the ECR, VMI and CPFR initiatives, which increases durability of items on shelves and customer satisfaction. On the other hand, a perceived equivalent benefit in the textile industry has been the reduction of price decreases. Better inventory planning was also cited, resulting in a better inventory management in supply chain in VMI and CPFR initiatives, thanks to the increased visibility of demand provided, when compared to QR and ECR initiatives. In fact, with VMI, responsibility for the customer's inventory is given to the suppliers, who are able to schedule their production to meet the actual demand of their customers, maintaining adequate inventory levels at their facilities and at the client's facilities. In the CPFR, with the joint planning process, the events and changes in demand patterns are taken into account for the best sizing of the stock in the supply chain.

- Better demand predictability: increasing demand visibility can reduce the bullwhip effect along the chain, allowing companies to plan their operations from more realistic forecasts. Two points that deserve attention in relation to this benefit is that in the CRP, manufacturers can improve their forecasts by eliminating the artificial fluctuations in demand generated by early purchasing practices and in the CPFR, the members achieve better forecasts thanks to the realization of the forecast in a collaborative way.

- Better planning: most authors cited this benefit as a result of CPFR, as might be expected, since one of their focuses is on collaborative planning.

- Replenishment process improvement: in the QR, the replenishment process is improved thanks to the reduction of the distribution cycle time; in the CRP by more frequent replenishments; in the VMI through the increase of the available information; in the ECR, it occurs by the reduction of the transportation, distribution and delivery times, simplifying the flow of products and increasing logistics efficiency; finally, in CPFR it is improved by joint planning process.

- Improvement of the productive cycle: in the $\mathrm{QR}$, the improvement of the productive cycle occurs with the increase of the speed of production 
and reduction of the waiting times. In ECR, it occurs due to increased productivity. In CRP, VMI and CPFR, it is a reflection of better production planning, thanks to the greater visibility of demand.

- Relationship improvement: increasing the level of business makes relationships more intimate and improves communication, trust and collaboration.

- Improved supply chain management: this occurs by reducing the inventory level and simplifying a range of processes, reducing errors and redundancies among supply chain links, and minimizing risk.

- Improvement of product assortment: this benefit is more relevant in ECR, since with category management, the ideal mix of products is offered to the final consumer.

- Improvement of promotional activities: this process is more relevant to the ECR, thanks to the activities of category management and adapting the promotional activities to the needs of the clients. Some authors cite the improvement of promotional activities as a benefit of CPFR, as companies are able to plan promotions collaboratively. In CRP, as expected, this benefit is not mentioned, since promotional activities should be avoided in order to avoid generating artificial oscillations in demand.

- Reduced cycle time: reduced cycle time and lead time are cited as benefits in the QR, ECR, VMI, and CPFR initiatives.

- Higher efficiency in product launching: it is also cited as a benefit of the ECR, due to the strategy of introducing efficient new products. Some authors affirm that the product launch process is improved with the $\mathrm{QR}$, with the reduction of the development time of the products.

\section{Secondary benefits}

- The secondary benefits achieved are: cost reduction; better level of customer service; better asset management; sales increase; profit increase; increased competitiveness; improved financial performance; greater customer responsiveness.

- Cost reduction: it occurs through the reduction of inventory level, stockouts, operational, administrative and logistic costs, obsolescence of products and less price reductions. Reviewing processes and activities between partners eliminates activities that do not add value.

- Better level of customer service: while VMI measures the level of customer service in terms of product availability in the ECR literature, 
it is understood differently and it is related to the real needs of consumers. This difference is due to the main focus of the two initiatives: while VMI focuses on the replenishment process, the ECR also highlights demandrelated aspects. With the ECR, companies begin to study consumer buying behavior and can better understand their expectations and needs. Therefore, they treat the level of customer service in a different way, considering more subjective aspects than the VMI.

- Better asset management: the initiatives promote better use of the assets, bringing a better return to them.

- Sales increase: these are perceived benefits with the adoption of the initiatives, also made possible by the reduction of lost sales.

- Profit increase: with the largest margin of products sold, thanks to cost savings along with increased sales.

- Increased competitiveness: companies that implement collaborative initiatives increase their competitiveness.

- Improved financial performance: collaborative initiatives promote increased cash flow and bring financial savings from better inventory management and improved replenishment process.

- Greater customer responsiveness: it was cited as a benefit of the QR, ECR and CPFR. The adoption of these initiatives makes it possible to respond more quickly to market needs. The work on CRP and VMI did not mention it as a benefit but as a reduction of lead time, coupled with the increase in demand information, contributing to an increase in responsiveness.

\subsubsection{Conceptual model of motivators, barriers and benefits in the process of adopting collaborative initiatives}

From the motivators, barriers and benefits of collaborative initiatives, a conceptual model can be proposed (Figure 3.2.4.1). Organizations are influenced by external factors and economic motivators and can also be impacted by internal factors and organizational motivators that can motivate the decision to implement a collaborative initiative. In this process, supply chain managers are faced with potential barriers (cultural, behavioral, or physical) that may impede their actual efficiency. Organizations must work to overcome or mitigate the effect of these barriers so that the initiatives start to bring benefits to businesses. Primary benefits must first be achieved, so secondary benefits can start to appear. 


\section{(Figure 3.2.4.1)}

\section{CONCEPTUAL MODEL OF MOTIVATORS, BARRIERS AND BENEFITS IN THE PROCESS OF ADOPTING COLLABORATIVE INITIATIVES}

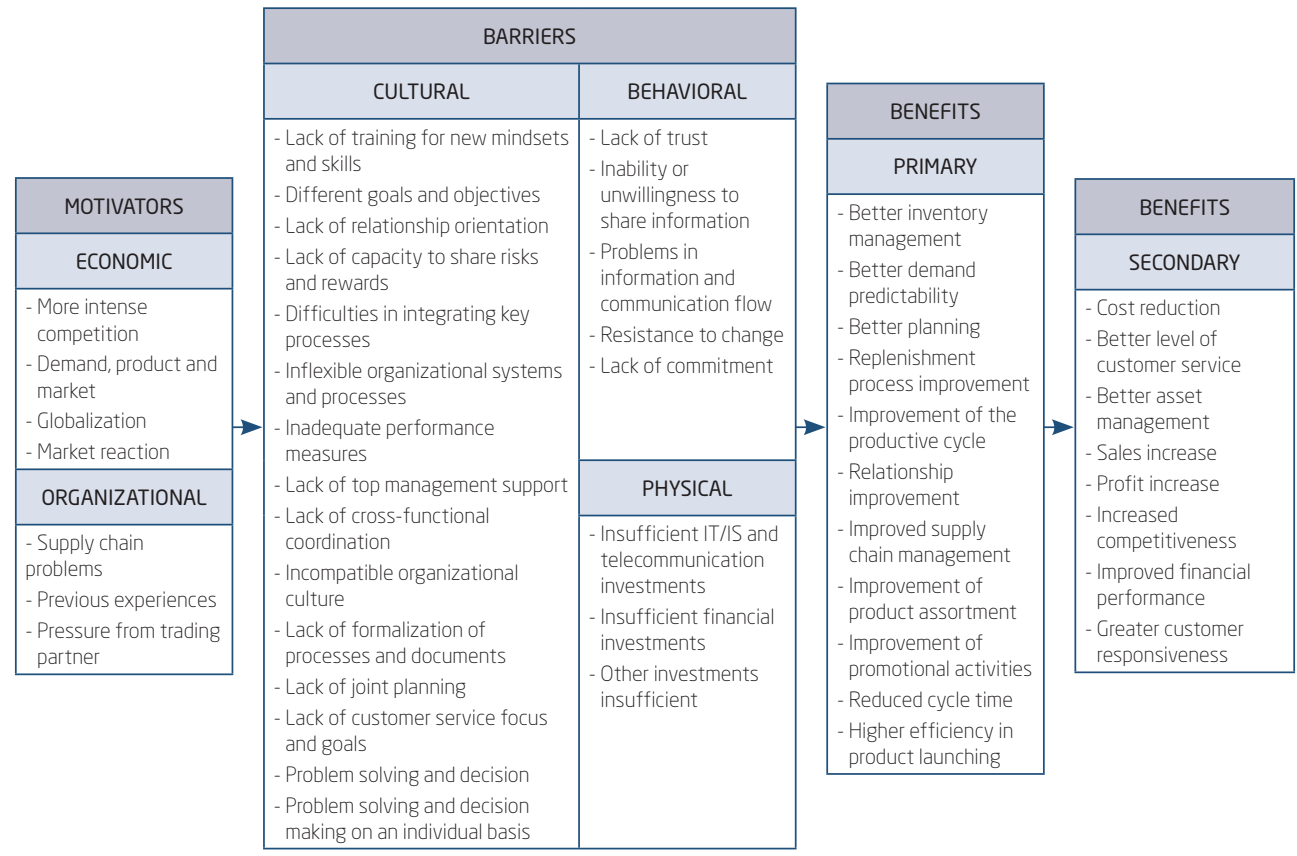

Source: Elaborated by the authors

When analyzing the environment in which the supply chain is operating, it is necessary to verify changes in the market that can cause an imbalance; that is, economic motivators that can stimulate the implementation of one or more initiatives. In addition, by analyzing internally the supply chain to which it belongs and the way it is organized and structured, the company must verify the presence of organizational factors that can motivate the adoption of a collaborative initiative.

In the implementation process, it is necessary to analyze the presence of barriers that may hinder the implementation of the initiative or the achievement of expected benefits. This analysis may highlight the need for cultural changes, behavior or even the need for investments. With the initiative in place, it is important to analyze its performance, verifying if the primary benefits are being achieved. The primary benefits are related to the improvement of supply chain processes and collaborative relationship. 


\section{FINAL CONSIDERATIONS}

This research had an exploratory, theoretical character and contributes to the systematization of existing knowledge, presenting from a systematic review of the literature, a theoretical classification of the different types of motivators, barriers and benefits existing in the processes of adoption of collaborative initiatives between companies in the supply chain and a conceptual model that explains the relationship between these variables. This paper presents an advance in supply chain management theory by classifying the motivators, barriers and benefits, showing an initial relationship of dependence between concepts, which opens up possibilities for further studies.

Some important points to highlight are the concept of service level that differs according to the objective of each company, being more related to objective aspects (efficiency) or more subjective aspects, related to the need of the consumers (effectiveness). Information and communication technologies, with the reduction of costs, are no longer a barrier and are a driving force in the development of collaborative initiatives. Supply chain management is already enabled through modern information technologies and its success is based on people, remembering that cultural and behavioral barriers are much more difficult to transpose than physical barriers. Finally, the issue of pressure by trading partners points to a possibility of unilateral collaboration, which goes against the principles of collaborative supply chain management.

In spite of the findings presented, it is important that the results found in this paper are validated and empirically improved, which may be considered as a limitation while open new directions for further research. Future studies can analyze the benefits, barriers and motivators perceived by companies and observe how business partners measure the benefits of the initiatives and what performance measures are used. Barrier-related studies should be aware of the fact that an overdue barrier can function as an important success factor later on. Analyzing the role of technology in developing relationships is an interesting topic.

In addition, studying how companies reduce impact or overcome each barrier can also bring important insight, helping future implementations. Another issue to be analyzed is related to the barrier here called "difficulties in the integration of key processes", since the literature does not explicitly mention which processes should be integrated with the adoption of each initiative. Finally, in relation to supply chain power, further studies may 
examine the possibility of small firms influencing the adoption of collaborative initiatives in their supply chains and may also confront the characteristics of a relationship that has been initiated by pressure onto a relationship that has been equally driven by the willingness from both parties.

\section{INICIATIVAS DE COLABORAÇÃO: MOTIVADORES, BARREIRAS E BENEFÍCIOS}

\section{)} RESUMO

Objetivo: Propor uma classificação dos diferentes tipos de motivadores, barreiras e benefícios existentes nos processos de adoção de iniciativas de colaboração entre empresas na cadeia de suprimentos.

Originalidade/relevância: Os resultados alcançados auxiliam os gestores a conhecerem os diferentes tipos de motivadores que impulsionam a adoção destas iniciativas, os benefícios que podem ser alcançados e as barreiras que podem ser encontradas, evitando implantações mal sucedidas. Para pesquisadores, fornecem um melhor entendimento teórico dos diferentes tipos de componentes presentes nestas iniciativas, abrindo caminho para a busca de evidências empíricas.

Principais aspectos metodológicos: Foi realizada uma revisão sistemática da literatura com foco em cinco iniciativas: Quick Response (QR), Efficient Consumer Response (ECR), Continuous Replenishment Program (CRP), Vendor Managed Inventory (VMI) e Collaborative Planning, Forecasting and Replenishment (CPFR).

Síntese dos principais resultados: Os motivadores para a adoção destas iniciativas estão relacionados às mudanças econômicas ou de mercado, e/ ou à forma de organização destas empresas. As barreiras foram classificadas em culturais, comportamentais e físicas e os benefícios foram classificados em primários e secundários, mostrando que os benefícios primários devem ser alcançados para que os benefícios secundários apareçam.

\section{$\int$ PALAVRAS-CHAVE}

Motivadores. Barreiras. Benefícios. Colaboração. Cadeia de suprimentos. 


\section{REFERENCES}

Attaran, M., \& Attaran, S. (2007). Collaborative supply chain management: The most promising practice for building efficient and sustainable supply chains. Business Process Management Journal, 13(3), 390-404. doi:10.1108/ 14637150710752308

Barratt, M., \& Oliveira, A. (2001). Exploring the experiences of collaborative planning initiatives. International Journal of Physical Distribution \& Logistics, 31(4), 266-289.

Bichescu, B. C., \& Fry, M. J. (2009). Vendor-managed inventory and the effect of channel power. OR Spectrum, 31 (1), 195-228. doi:10.1007/s00291007-0102-7

Birtwistle, G., Fiorito, S. S., \& Moore C. M. (2006). Supplier perceptions of quick response systems. Journal of Enterprise Information Management, 19(3), 334-345. doi:10.1108/17410390610658504

Birtwistle, G., Siddiqui, N., \& Fiorito, S. S. (2003). Quick Response: Persepctions of UK fashion retails. International Journal of Retail \& Distribution Management, 31 (2), 118-128 doi:10.1108/09590550310462010

Blackhurst, J., Craighead, C. W., \& Handfield, R. B. (2006). Towards supply chain collaboration: an operations audit of VMI initiatives in the electronics industry. International Journal of Integrated Supply Management, 2(1/2), 91-105. doi:10.1504/IJISM.2006.008340

Buchinger, D., Cavalcanti, G. A. de S., \& Hounsell, M. da S. (2014). Mecanismos de busca acadêmica: uma análise quantitativa. Revista Brasileira de Computação Aplicada, 6(1), 108-120. doi:10.5335/rbca.2014.3452

Caridi, M., Cigolini, R., \& Marco, D. de. (2006). Linking autonomous agents to CPFR to improve SCM. Journal of Enterprise Information Management, 19(5), 465-482. doi:10.1108/17410390610703620

Chang, T.-H., Fu, H.-P., Lee, W.-I., Lin, Y., \& Hsueh, H.-C. (2007). A study of an augmented CPFR model for the 3C retail industry. Supply Chain Management: An International Journal, 12(3), 200-209. doi:10.1108/13598 540710742518

Chen, M.-C., Yang, T., \& Li, H.-C. (2007). Evaluating the supply chain performance of IT-based inter-enterprise collaboration. Information $\mathcal{E}$ Management, 44(6), 524-534. doi:10.1016/j.im.2007.02.005

Colicchia, C., \& Strozzi, F. (2012). Supply chain risk management: a new methodology for a systematic literature review. Supply Chain Management: An International Journal, 17 (4), 403-418. doi:10.1108/13598541211246558 
Danese, P. (2007). Designing CPFR collaborations: insights from seven case studies. International Journal of Operations \& Production Management, 27(2), 181-204. doi:10.1108/01443570710720612

Denyer, D., \& Tranfield, D. (2009). Producing a systematic review. In D. A. Buchanan \& A. Bryman (Eds.), The Sage Handbook of Organizational Research Methods (pp. 671-689). London: Sage Publications.

Derrouiche, R., Neubert, G., \& Bouras, A. (2008). Supply chain management: a framework to characterize the collaborative strategies. International Journal of Computer Integrated Manufacturing, 21(4), 426-439. doi:10.1080/ 09511920701574461

Disney, S. M., \& Towill, D. R. (2003). Vendor-managed inventory and bullwhip reduction in a two-level supply chain. International Journal of Operations \& Production Management, 23(6), 625-651. doi:10.1108/0144357 0310476654

Fawcett, S. E., Magnan, G. M., \& McCarter, M. W. (2008). Benefits, barriers, and bridges to effective supply chain management. Supply Chain Management: An International Journal, 13 (1), 35-48. doi:10.1108/13598540810850300

Forza C., \& Vinelli, A. (1997). Quick response in the textile-apparel industry and the support of information technologies. Integrated Manufacturing Systems, $8(3), 125-136$.

Freitas, D. C. de, Tomas, R. N., \& Alcântara, R. L. C. (2014). Análise da prática Vendor Managed Inventory (VMI) em um fornecedor de bens de consumo. Produção Online, 14(3), 1024-1049. doi:10.14488/1676-1901. v14i3.1654

Fu, H.-P., Chu, K.-K., Lin, S.-W., \& Chen, C.-R. (2010). A study on factors for retailers implementing CPFR: A fuzzy AHP analysis. Journal of Systems Science and Systems Engineering, 19(2), 192-209. doi:10.1007/s11518-0105136-8

Gao, X., Liu, J., \& Liu, D. (2005). Supply Chain Coordination: A review. Journal of Systems Science and Information, 3(3), 569-584.

Gomes, L. de C., \& Kliemann, Neto F. J. (2015). Métodos colaborativos na gestão de cadeias de suprimentos: Desafios de implementação. Revista de Administração de Empresas, 55(5), 563-577.

Harris, J. K., Swatman, P. M. C., \& Kurnia, S. (1999). Efficient consumer response (ECR): A survey of the Australian grocery industry. Supply Chain Management: An International Journal, 4(1), 35-42. doi:10.1108/135985 49910255077 
Hoffman, J. M., \& Mehra, S. (2000). Efficient consumer response as a supply chain strategy for grocery businesses. International Journal of Service Industry Management, 11 (4), 365-373.

Kauremaa, J., Småros, J., \& Holmström, J. (2009). Patterns of vendormanaged inventory: Findings from a multiple-case study. International Journal of Operations \& Production Management, 29(11), 1109-1139. doi:10.1108/ 01443570911000159

Kumar, S. (2008). A study of the supermarket industry and its growing logistics capabilities. International Journal of Retail \& Distribution Management, 36(3), 192-211. doi:10.1108/09590550810859150

Lee, S. C., Pak, B. Y., \& Lee, H. G. (2003). Business value of B2B electronic commerce: The critical role of inter-firm collaboration. Electronic Commerce Research and Applications, 2, 350-361.

Mangiaracina, R., Melacini, M., \& Perego, A. (2012). A critical analysis of vendor managed inventory in the grocery supply chain. International Journal of Integrated Supply Management, 7(1/2/3), 138-166.

Marquès, G., Lamothe, J., Thierry, C., \& Gourc, D. (2012). A supply chain performance analysis of a pull inspired supply strategy faced to demand uncertainties. Journal of Intelligent Manufacturing, 23(1), 91-108. doi:10.1007/ s10845-009-0337-z

Marqui, A. C., Moura, K. S., \& Alcântara, R. L. C. (2013). Collaborative supply chain: A conceptual model for operationalization. International Journal of Management and Decision Making, 12(3), 195-214.

Okoli, C., \& Schabram, K. (2010). A guide to conducting a systematic literature review of information systems research. Sprouts: Working Papers on Information Systems, 10(26), 10-26.

Pecar B., \& Davies B. (2007). A new technology paradigm for collaboration in the supply chain. International Journal of Services Operations and Informatics, 2(3), 300-314.

Raghunathan, S., \& Yeh, A. B. (2001). Beyond EDI : Impact of continuous replenishment program (CRP) between a manufacturer and its retailers. Information Systems Research, 12(4), 406-419.

Razmi, J., Rad, R. H., \& Sangari, M. S. (2010). Developing a two-echelon mathematical model for a vendor-managed inventory (VMI) system. The International Journal of Advanced Manufacturing Technology, 48, 773-783. doi:10.1007/s00170-009-2301-7 
Savaşaneril, S., \& Erkip, N. (2010). An analysis of manufacturer benefits under vendor managed systems. IIE Transactions, 42 (7), 455-477. doi:10. 1080/07408170903459968

Seuring, S., \& Gold S. (2012). Conducting content-analysis based literature reviews in supply chain management. Supply Chain Management: An International Journal, 17(5), 544-555. doi:10.1108/13598541211258609

Soret, I., Pablos, C. de, \& Montes, J. L. (2008). Efficient consumer response (ECR) practices as responsible for the creation of knowledge and sustainable competitive advantages in the grocery industry. Issues in Informing Science and Information Technology, 5, 601-621.

Tranfield, D., Denyer D., \& Smart P. (2003). Towards a methodology for developing evidence-informed management knowledge by means of systematic review. British Journal of Management, 14, 207-222.

Tyan, J., \& Wee, H.-M. (2003). Vendor managed inventory: a survey of the Taiwanese grocery industry. Journal of Purchasing and Supply Management, 9(1), 11-18. doi:10.1016/S0969-7012(02)00032-1

Vigtil, A., \& Dreyer, H. C. (2008). Critical aspects of information and communication technology in vendor managed inventory. IFIP International Federation for Information Processing, 1-8.

Whipple, J. M., \& Russell, D. (2007). Building supply chain collaboration: a typology of collaborative approaches. The International Journal of Logistics Management, 18(2), 174-196. doi:10.1108/09574090710816922

Wong, C., Skipworth, H., Godsell, J., \& Achimugu, N. (2012). Towards a theory of supply chain alignment enablers: A systematic literature review. Supply Chain Management: An International Journal, 17(4), 419-437. doi:10. 1108/13598541211246567

Yao, Y., \& Dresner, M. (2008). The inventory value of information sharing, continuous replenishment, and vendor-managed inventory. Transportation Research Part E: Logistics and Transportation Review, 44, 361-378. doi:10.1016/j. tre.2006.12.001

Denise C. de Freias, Production Engineering, Universidade Federal de São Carlos; Leandro G. de Oliveira, Production Engineering, Universidade Federal de São Carlos; Rosane L. C. Alcantara, Business Administration, Fundação Getúlio Vargas. 
Denise C. de Freitas is now a Professor at the Instituto Federal de São Paulo; Leandro G. de Oliveira is now a PhD candidate at Universidade Federal de São Carlos; Rosane L. C. Alcantara is now a Professor at Universidade Federal de São Carlos.

Correspondence concerning this article should be adressed to Rosane L. C. Alcantara, Rodovia Washington Luiz, km 235, Monjolinho, São Carlos, SP, Brazil, CEP 13565-905.

E-mail: rosane@ufscar.br

\section{EDITORIAL BOARD}

Editor-in-chief

Silvio Popadiuk

Associated Editor

Thais Vick

(iD) https://orcid.org/0000-0003-4869-7612

Technical Support

Vitória Batista Santos Silva

\section{EDITORIAL PRODUCTION}

Publishing Coordination

Irina Migliari

Editorial Trainee

Maria Luiza Vanz

Copyeditor

Irina Migliari
Language Editor

Daniel Leão

Layout Designer

Emap

Graphic Designer

Libro 